\title{
A cinema for the unborn: moving pictures, mental pictures and Electra Sparks's New Thought film theory
}

\author{
PATRICK ELLIS*
}

\begin{abstract}
In the 1910s, New York suffragette Electra Sparks wrote a series of essays in the Moving Picture News that advocated for cine-therapy treatments for pregnant women. Film was, in her view, the great democratizer of beautiful images, providing high-cultural access to the city's poor. These positive 'mental pictures' were important for her because, she claimed, in order to produce an attractive, healthy child, the mother must be exposed to quality cultural material. Sparks's championing of cinema during its 'second birth' was founded upon the premise of New Thought. This metaphysical Christian doctrine existed alongside the self-help and esoteric publishing domains and testified, above all, to the possibility of the 'mind-cure' of the body through the positive application of 'mental pictures'. Physiologically, their method began best in the womb, where the thoughts of the mother were of utmost importance: the eventual difference between birthing an Elephant Man or an Adonis. This positive maternal impression was commonplace in New Thought literature; it was Sparks's innovation to apply it to cinema. Investigating Sparks's film theory, practice and programming reveals her to be a harbinger of the abiding analogy between mind and motion picture that occupies film theorists to this day.
\end{abstract}

In 1911, Electra Sparks (the nom de plume of Mary Lawton Metcalfe) began writing for the Moving Picture News, a New York-based trade journal. ${ }^{1}$ In some sixteen essays, she

* School of Literature, Media, and Communication, Georgia Institute of Technology, 215 Bobby Dodd Way NW, Atlanta, GA 30332, US. Email: pgellis@gatech.edu.

I am grateful above all to my co-editors Jesse Olszynko-Gryn and Caitjan Gainty for years of good discussion, advice and fellowship. For commentary and notes on earlier versions of this essay, I owe thanks to Nick Hopwood, Mark Sandberg and Richard Staley. The Reproduction on Film conference and a panel, chaired by Kirsten Ostherr, at the Society for Cinema and Media Studies Conference in Atlanta in 2016 helped the article's development, and at the latter location I was glad to have been joined by Oliver Gaycken and Janina Wellmann.

1 She used the name 'Electra Sparks' erratically - overall, a greater number of articles were written under her given name, Mary Lawton Metcalfe, which I use in the notes so that readers may reliably source her writing. However, her key essays in film theory were written as Sparks, and accordingly I use her nom de plume in the body of the text. Moreover, electricity was a recurrent theme in her writing and theory, connected, esoterically, to the power of New Thought. For instance, giving a speech to the Staten Island Women's Club, she claimed that, cumulatively, 'Vitalizing words from you earnest, thoughtful women will generate and transmit a current of positive electricity, which will carry us upward into a purer atmosphere of intellectuality, spirituality, progressive thinking and forceful doing'. See 'Clubwomen capture Dongan Hills Fair', Staten Island World, 17 September 1910, p. 2. For a short, biographical essay on Sparks see Patrick Ellis, 'Mary Lawton Metcalfe', in Jane Gaines, Radha Vatsal and Monica Dall'Asta (eds.), Women Film Pioneers Project, New York: Columbia University Libraries, 2013, published online 1 May 2017, at https://wfpp.cdrs. columbia.edu/pioneer/mary-lawton-metcalfe. 
advocated variously for the moral reform of cinema; for the use of moving pictures in education; for a correspondent broadening of moving pictures to new screening locations; and for a form of filmic treatment, a cine-therapy, for pregnant women.

The Moving Picture News was above all concerned with promoting educational cinema and identifying new markets for it. ${ }^{2}$ This position obliged the journal to take a stance against outright bans on cinema in schools, but in favour of its wider censorship; it was part of a debate around the place of film that was still being held in communities across the United States, as it would be for many years. ${ }^{3}$ The editors' championing of educational cinema pitted them against clergymen and educators, whose vexed letters they printed, and whom they attempted to persuade in the pages of the journal.

Electra Sparks was a strategic invitation to the Moving Picture News, insofar as she had religious and educational bona fides, was involved in the who's who of society life in Staten Island and New York City, and had accomplished work that was thematically in line with pre-existing causes of the journal. ${ }^{4}$ However, she went far beyond the journal's editorial norms in style, fervour and the ambitions of her demands. She took cinema-education advocacy to its very limit. 'There is a bomb I am going to throw right into educational circles' - the bomb of moving pictures. ${ }^{5}$

Alongside advertisements for movie theatre technologies, reports from foreign markets, announcements and synopses of current films, the editors might normally recommend that every New York school purchase a movie projector; Sparks went further, demanding that every university, public library, Sunday school and church have one. ${ }^{6}$ Margaret I. MacDonald, the writer who invited Sparks to join the magazine's roster, made weekly visits to New York City movie theatres in order to push for educational

2 On the utopian pedagogical aims of early film boosters and 'the flowering of interest in cinema as an educational medium around 1910' see Oliver Gaycken, 'The cinema of the future: visions of the medium as modern educator, 1895-1910', in Devin Orgeron, Marsha Orgeron and Dan Streible (eds.), Learning with the Lights Off: Educational Film in the United States, Oxford: Oxford University Press, 2012, pp. 67-89, 86.

3 For a detailed case study on New York censorship policies directly preceding the timeline of this essay see Lee Grieveson, “"A kind of recreative school for the whole family”: making cinema respectable, 1907-09', Screen (2001) 42, pp. 64-76.

4 Sparks moved within the actual who's who of Staten Island life. Many of the attendees at the talk cited above (note 1) were featured in a period edition of the Woman's Who's Who of America, including the composer Anita Comfort-Brooks and the poet Ella Wheeler Wilcox. See John William Leonard, Woman's Who's Who of America: A Biographical Dictionary of Contemporary Women of the United States and Canada, 1914-1915, New York: American Commonwealth, 1915.

5 Mary Lawton Metcalfe, 'A practical plan for teaching without books', Moving Picture News (9 December 1911) 4, pp. 6-7, 7.

6 She demanded moving pictures 'to provide the university extension course', 'to promote the sanitation of every community', 'to be the vestibule of every public library', 'to fill the benches at Sunday school', 'to get the dust off the family Bible', and 'to help the preacher'. See Mary Lawton Metcalfe, 'Snips and snaps of news by a peripatetic camera', Moving Picture News (25 May 1912) 5, pp. 28-29. Note that the more familiar term 'motion picture' was used more or less interchangeably with 'moving picture' at this stage of film history, but Sparks used the latter exclusively. In order to clearly relay her theories, I have used this term throughout to refer to the 'movies'. 
programming; Sparks began her own matinee series and did it herself. ${ }^{7}$ A Chicago asylum's plan to treat its patients with 'an entertainment of moving pictures as a curative means' might receive a modest, sceptical notice in the Moving Picture News; Sparks, by contrast, called for an entirely new, curative cinema, one which would encourage mothers to develop the right thoughts by which they could positively 'mark' their embryonic child as they viewed a film: she called for a cinema for the unborn. ${ }^{8}$

Electra Sparks (1859-1949) had shifting bylines from week to week. Consolidated, they produce an eclectic CV; annotated, they offer an outline of her causes and enterprises in her most active period:

- Lecturer: delivering a 'rapid-fire lecturette' at a moment's notice, including talks on 'The psychology of the moving picture' and 'The moving picture to the good'.'

- Newspaper advice columnist: 'the Dorothy Dix of the Staten Island World' ${ }^{10}$

- Silk advocate: chairman of Central Committee Scientific Silk Culture. ${ }^{11}$

- Education reformer: secretary of the Society of Human Culture. ${ }^{12}$

- Film programmer and theorist: president of the People's Club of Patriotic Education. ${ }^{13}$

- Suffragette: president, Economics and Politics Club, New York City Federation. ${ }^{14}$

- Patriot: Daughter of the American Revolution - 'but just change the R into an E and you have a daughter of Evolution, which I really am'. ${ }^{15}$

- Christian: New Thought evolutionist, 'and therefore not a bit stuck up'. ${ }^{16}$

There is much in this vita that prompts curiosity, for to gather Sparks's activities in this way is to constellate largely forgotten influences. She was at the nexus of two marginal domains of intellectual life in the United States that coincided in the 1910s: the peak of a metaphysical Christianity then known as New Thought; and the beginning of (what we now call) classical film theory. Both fields shared an interest in the concept of 'mental

7 MacDonald's weekly accounts of the theatres of New York, including interviews with the proprietors, would provide an excellent basis for a study of regional exhibition practice in the 1910s.

8 On the Chicago asylum see Margaret I. MacDonald, 'Innovations in the use of the motion picture: educational and curative', Moving Picture News (14 January 1911) 4, p. 7; on marking the embryo see Mary Lawton Metcalfe, 'First impressions of living pictures - the manufacture of mental films - how to project memory pictures: scientific principles of psychology in human reproduction', Moving Picture News (4 November 1911) 4, pp. 14-15, 15.

9 Mary Lawton Metcalfe, 'Mental films of Christmas scenes and news items of Greater New York', Moving Picture News (23 December 1911) 4, pp. 6-7, 7.

10 Margaret I. MacDonald dubbed Metcalfe this in a biographical item, 'Mrs. Mary Lawton Metcalfe gives the moving picture first place as an educator', Moving Picture News (28 October 1911) 4, pp. 6-7. Although the staff at the Staten Island Museum, one of the few holders of this newspaper, was unable to locate examples of Sparks's advice column, I have no reason to doubt MacDonald's claim.

11 Mary Lawton Metcalfe, letter, 'American silk culture', New York Times, 1 November 1903, p. 6.

12 Mary Lawton Metcalfe, letter, 'The cry for education', New York Times, 16 March 1902, p. 5.

13 Mary Lawton Metcalfe, 'Sparks from the wires', Moving Picture News (6 April 1912) 5, pp. 12-13.

14 Mary Lawton Metcalfe, 'Snapshots: women's views of vital interest to moving picture trade', Moving Picture News (13 April 1913) 7, p. 23.

15 MacDonald, op. cit. (10).

16 Metcalfe, op. cit. (13), p. 12. 
pictures', images that we see in our mind's eye: for New Thought believers, they were healing visualizations to be kept in mind alongside prayer; and for film theorists such as Hugo Münsterberg, mental pictures were those processes of mind transformed by cinema. Moving pictures, and their impact on the mind, were important for each, who shared a belief that the mind was, in effect, 'photosensitive' - but Electra Sparks alone synthesized these divergent philosophies and activated them as practice.

She did so against a background of a neo-Lamarckism that allowed for the culturally acquired traits of the parent to be passed on to the child, a belief that coincided with an early revival of cinema, when millions were first seeing moving pictures on thousands of screens. These phenomena together created a concern for cinematic epigenetics that has ebbed and flowed through film history. What is the physiological effect of this immersive medium, and how does this effect alter the viewer and her children? Here, I recover Sparks's work not only for historians of science and medicine, as a demonstration of the public understanding of maternal impression at the beginning of the twentieth century, but also for film historians, for whom this missing theory of film will resonate with today's immersive media landscape. I relate Sparks's work not only to her spiritual milieu, and to the film theory of her day (via Hugo Münsterberg, who shared her attitude to film), but also to film and media theory of today. In each instance, we see the enthusiasts of the new medium moving past immediate medicalization concerns toward a generational logic: from the viewer reproducing the emotions or aesthetics on screen within themselves, to the viewer reproducing children that have internalized and carry within them these aesthetic structures of the screen.

\section{Moving pictures and mental pictures}

A premise of Electra Sparks's film theory is that the moving picture is an appropriate new media metaphor for the processes of the mind. She offers an evocative account of a routine experience of vision and cognition:

Through the lens of the human eye, upon the camera of the conscious observing faculties, located in the nerves of the brain, sights and scenes are being printed incessantly of passing objects and scenes.

There are, therefore, millions of mental-picture galleries of past views of real happenings. Mental pictures of happenings in farce, comedy, tragedy, indeed stories of joy and sorrow are incessantly being stamped on the mental films of every conscious creature. ${ }^{17}$

Just as the retinal purple of the eye was then thought to be sensitive to light in much the same way as the Kodak camera, the mind, for Sparks, operated like a moving picture. ${ }^{18}$ This type of physiological-medial correlation has a long history. Think of Marx's

17 Mary Lawton Metcalfe, 'Moving pictures and illustrated stereopticon teaching: the lever for progressive auxiliary education (a lecture at the Gotham Club, Dec. 5)', Moving Picture News (16 December 1911) 4, pp. 9-10, 9.

18 For a discussion of Willy Kühne's optography experiments, which provide the premise for the analogy, see George Wald, 'Eye and camera', in Dennis Flanagan (ed.), Scientific American Reader, New York: Simon \& Schuster, 1953, pp. 555-568. 
famous borrowing of the phantasmagoria to explain commodities, or of the moving panorama as the default reference for the aerial view. Today, the media metaphor of choice for the mind is the computer. ${ }^{19}$ In 1911, it was the moving picture.

This comparison between mind and film was typical of some of the most important classical film theorists, above all Hugo Münsterberg. ${ }^{20}$ Sparks, however, took this premise in an unforeseen direction. What Münsterberg thought to be a temporary mental mimicry of the screen - for instance, when the viewer sees a dizzy person on screen, and experiences dizziness in turn - Sparks took to be permanent. 'We know', she claimed, 'that the eye learns more rapidly than the ear; and that it is the scenes impressed upon this brain-camera that make indelible impression'. ${ }^{21}$ This indelibility was her concern. Mental pictures were commensurate with the soul. ${ }^{22}$ Cinema was, in 1911, just entering its 'second birth', with dedicated screening locations and a reputation that was less dependent upon its sister arts; it was emerging as a dominant medium and industry rather than a novel technology. ${ }^{23}$ More and more people were going to the movies, so the moral quality of images presented was of crucial importance. Mental pictures, delivered via moving pictures, could affect powerful change on the viewer, positive or negative. Images viewed on screen were, Sparks claimed in a lecture at the Gotham Club, 'truly being stored up in the realm of the subconscious mind, that mysterious power house, the heaven or hell in the moving world of constructive thinking to the good or to the bad'. 24

Sparks's concerns were not merely behavioural - the 'Wild West thrillers' that she deplored were not to be avoided because they could encourage crime, as reformers have perennially insisted - rather, her concerns were physiological. ${ }^{25}$ Exposure to morally corrupt films could warp the viewer and produce illness and disease; concomitantly, exposure to virtuous films could produce positive physical change. This was true for adults and children freely choosing to visit the movie theatre, but Sparks's special concern was for the unborn, brought there without choice. They, she proposed, might be permanently corrupted:

Thousands of unborn children could be numbered in the audiences of all nations where moving picture theaters are established.

Shall women pregnant with 'future hopes' of nations for universal peace be impressed for war?

19 See David Bates, 'Insight in the age of automation', in Darrin McMahon and Joyce Chaplin (eds.), Genealogies of Genius, Basingstoke: Palgrave McMillan, 2015, pp. 153-169; on the aerial view see Patrick Ellis, 'Aeroscopics: spectacles of the bird's-eye view', PhD thesis, University of California at Berkeley, 2017.

20 Not to give the wrong impression: for every early film theorist who noted symmetry between mind and cinema, there was another who noted asymmetry.

21 Mary Lawton Metcalfe, 'Moving pictures aid in education', Moving Picture News (21 September 1912) 6, p. 19.

22 'Mental pictures' was her preferred term, over the 'brain-camera' or 'mental films', used elsewhere sporadically, and synonymously.

23 See Andrew Shail (ed.), Cinema's Second Birth, special issue of Early Popular Visual Culture (2013) 2.

24 Metcalfe, op. cit. (17), p. 10.

25 Metcalfe, op. cit. (14), p. 23. 
Shall unborn boys thirst for the blood of human brothers through the mental pictures of the mother? ${ }^{26}$

The terminology here indicates that Sparks is familiar with the theory of 'maternal impression': that the future child was vulnerable to the mother's imagination and (especially) visual and cultural experiences in utero, and that these experiences could determine the eventual difference between birthing an Elephant Man or an Adonis. A standard, apocryphal example would be the mother who sees a dwarf while pregnant, and goes on to give birth to a dwarf. The mother and the foetus, temporarily impressible, respond to visual stimulus. Originating in antiquity, the concept of maternal impression survived for centuries in both learned and vernacular discussion of reproduction. ${ }^{27}$ By the eighteenth century, natural philosophers and physicians tended to dismiss the theory as an unscientific superstition associated with notorious hoaxes, such as that of Mary Toft, who in 1726 claimed to have delivered rabbits after seeing a rabbit. But reports of maternal impressions persisted in medical journals even around the year $1900 .{ }^{28}$ It was prominent in Aristotle's Masterpiece (1684), one of the most widely circulated books on sex and reproduction in the English language, through its many editions and reprintings, and endured into the twentieth century as a common explanation for deformities, birthmarks and character traits. ${ }^{29}$ So, too, does it continue today, when the theory has been recast as a form of populist proto-epigenetics. ${ }^{30}$

Sparks's advocacy for a cinema for the unborn was inspired by the positive mind-cure tenets of the 'New Thought people', for whom maternal impression was an article of faith, and who ordered their believers to 'write only to the good'. ${ }^{31}$ Sparks was correspondingly more interested in creating a race of Adonises than she was in preventing deformity. New Thought, a motley allegiance of small metaphysical Christian groups, favoured mesmerism, magnetic cures and faith healing, among other disputed treatments. Because they believed that the disposition of the mind had the power to impact the body, there was an institutional tendency to articulate their methods in terms of uplift and goodness.

26 Mary Lawton Metcalfe, 'Psychological power of moving pictures - constructive rather than destructive ideas to be impressed - fear is an emotion to be eliminated from all education', Moving Picture News (11 November 1911) 4, pp. 7-8, 8 .

27 On maternal impression in antiquity (and beyond) see T.W. Glenister, 'Fantasies, facts, and foetuses: the interplay of fantasy and reason in teratology', Medical History (1964) 8, pp. 15-30.

28 Paul Gabriel-Boucé, 'Imagination, pregnant women, and monsters in eighteenth-century England and France', in G.S. Rousseau and Roy Porter (eds.), Sexual Underworlds of the Enlightenment, Manchester: Manchester University Press, 1987, pp. 86-100; Dennis Todd, Imagining Monsters: Miscreations of the Self in Eighteenth-Century England, Chicago: The University of Chicago Press, 1995. On maternal impression in nineteenth- and twentieth-century medicine see Salim Al-Gailani, “"Antenatal affairs”: maternal marking and the medical management of pregnancy in Britain around 1900', in Urte Helduser and Burkhard Dohm (eds.), Imaginationen des Ungeborenen/Imagining the Unborn, Heidelberg: Winter-Verlag (in press).

29 Mary E. Fissell, 'Making a masterpiece: the Aristotle texts in vernacular medical culture', in Charles E. Rosenberg (ed.), Right Living: An Anglo-American Tradition of Self-Help Medicine and Hygiene, Baltimore: Johns Hopkins University Press, 2003.

30 See Sarah S. Richardson, The Maternal Imprint, Chicago: The University of Chicago Press, forthcoming.

31 Metcalfe, op. cit. (9), p. 7. 
Sparks believed that film could be the great democratizer of beautiful images - or, more worryingly, a leveller of ugly ones. Every change in the image on screen, good or bad, left a corresponding mark on the viewer. She was not alone in this. Even the film critics of Hollywood industry papers, such as Variety, were concerned that negative images on screen could impress themselves upon the pregnant mother and the foetus. ${ }^{32}$ In this way, the dream of maternal impression was, as Lorraine Daston has observed, the dream of a perfect, receptive medium that reproduced external stimuli. ${ }^{33}$ The foetal 'viewer' was so passive as to reproduce the qualities of the new medium of moving pictures; so passive as to become, essentially, an extension of the film: a foetal medium. As Sparks framed it, with the bolded text that she often favoured,

Constant scenes of beauty cannot fail to make a brand new mental-film on the minds of unborn children. But you ask me how are the city's poor to get the inspiring scenes of nature; the breezy scent of early dawn from the meadows? How are expectant mothers to enjoy the flowers and fields and see young lambs frisking on the hillside and run to their mothers for milk? And I answer you: The Moving Picture Is the People's Theater. ${ }^{34}$

Sparks's theory of film was, as she referred to it, a 'glorious New Thought hash'. ${ }^{35}$ A selfprofessed New Thought adherent, her ideas about cinema are expressly inspired by its teachings. Indeed, the ideas of the moving picture as metaphor for mind, of the mental picture as concept for mind, and of the pre- and post-natal physiological power of art are all embedded in New Thought teachings. ${ }^{36}$ Who, then, were the 'New Thought people'?

\section{Metaphysical obstetrics}

New Thought was an umbrella term for a diverse array of groups - some of which adopted the term, some not - that participated in the mind-cure movement that occupied metaphysical Christianity in the United States at the turn of the nineteenth century. As a sympathetic critic framed it, 'The New Thought like Christian Science affirms the supremacy of Mind[.] It holds that all diseases are of mental origin and are curable by mental means'. ${ }^{37}$ New Thought emerged in the 1890 s and was largely gone by

32 See Martin Pernick, The Black Stork: Eugenics and the Death of 'Defective' Babies in American Medicine and Motion Pictures since 1915, Oxford: Oxford University Press, 1999, p. 123.

33 Lorraine Daston, 'Projection and perfect passivity', in Natascha Adamowsky, Robert Felfe, Marco Formisano, Georg Töpfer and Kirsten Wagner (eds.), Affektive Dinge: Objektberührungen in Wissenschaft und Kunst, Göttingen: Wallstein, 2011, pp. 24-50.

34 Metcalfe, op. cit. (8), p. 15.

35 Metcalfe, op. cit. (6).

36 Based on her terminology, it is probable that she was a member of the (still-extant) Unity Church. At any rate she cites Charles Fillmore, co-founder of the church and its journal (and an avid filmgoer). In her later, Florida years, she was a member of the Golden Glow Bible Club.

37 Leon Cushing Prince, The Sense and Nonsense of Christian Science, Boston: Gorham, 1911, p. 14. Of course, New Thought had its outright critics, as well. Journalist H.L. Mencken was one of the most caustic. Perhaps inspired by Mark Twain's famous attack on Mary Baker Eddy, Mencken characterized the New Thought philosophy as a mere 'gaseous armamentarium'. See H.L. Mencken, 'The war against war', Chicago Tribune, 24 July 1927, p. F1; and Mark Twain, Christian Science, New York: Harper \& Brothers, 1907. 
1920..$^{38}$ The full extent of the movement is difficult to quantify, since terminology was not invariably shared among groups, but in the time that Electra Sparks was writing, historian Beryl Satter has estimated, there were around 350 New Thought centres in North America and six journals with circulation in the thousands. ${ }^{39}$ Materially, the self-help book was New Thought's greatest success. Many of its publications sold well enough to be published in multiple editions: Phrenopathy of Rational Mind-Cure (1898), The New Thought Simplified (1904), Christian Mind Healing (1915), and many others. The body of work has warranted several dedicated archives and library collections. ${ }^{40}$ Beyond this, there were prominent New Thought cultural producers - most famously the poet Ella Wheeler Wilcox of 'laugh and the world laughs with you' fame - and the cartoonist Richard F. Outcault, creator of the Yellow Kid, the iconic comic strip character. Like Sparks, these producers were operating at the level of the 'high low-brow', as it was then pejoratively called: in short, ambitious populism. ${ }^{41}$ Their New Thought beliefs, in every instance, heavily informed their work.

In the pages of New Thought journals, alongside mind-cure techniques, one might find pieces on telepathy, yoga, psychometry and astrology; depending on one's point of view, it was either a benign, 'popular intellectual discourse', ${ }^{42}$ or a 'riot of individualism', 'a nebulous compound of agnosticism, pantheism, esoteric Buddhism and Christianity'. ${ }^{43}$ This melange was in any case an institutional strength, at the time, insofar as it allowed diverse strands of mind-cure thought to consolidate and, potentially, to compete with Mary Baker Eddy's Christian Science, the rival metaphysical doctrine that successfully formalized its practice - and which, unlike the majority of New Thought groups, remains active today. ${ }^{44}$

The relationship between New Thought and Christian Science is contested, and is addressed in all New Thought histories. Both New Thought and Christian Science were inspired, originally, by the mesmerist Phineas Quimby in the mid-nineteenth

38 It continues to this day in some forms, with a small group of churches that consider their organizations a direct part of the tradition, as well as various mind-cure philosophies inspired by New Thought, but without necessarily a sense of its longer past. Historians have placed in this tradition such various outlets as Dale Carnegie's How to Win Friends and Influence People, New York: Simon \& Schuster, 1936; and, in our own time Rhonda Byrne's film The Secret (2006). The 1920s end date that I quote above is proposed in Beryl Satter, Each Mind a Kingdom: American Women, Sexual Purity, and the New Thought Movement, 1875-1920, Berkeley: University of California Press, 2001, p. 249.

39 Satter, op. cit. (38), p. 225.

40 For a still-useful survey of New Thought's archival scene in the 1960s see Charles Braden, Spirits in Rebellion: The Rise and Development of New Thought, Dallas: Southern Methodist University Press, 1963. The secondary literature on New Thought is surprisingly slim, compared to the extensive body of work its practitioners left behind. For popular fiction influenced by the tenets of New Thought see Satter, op. cit. (38), p. 6.

41 The 'high low-brow' would include, around 1911, 'Musical comedy, Richard Harding Davis, euchre, baseball, Anthony Hope, moving pictures, small steak medium, Ella Wheeler Wilcox'. See Out West (March 1911) 1, pp. 221-23, 222.

42 Satter, op. cit. (38), p. 9.

43 Prince, op. cit. (37), pp. 16, 15.

44 'They called their beliefs Mental Science, Divine Science, Spiritual Science, Unity, Mind Cure, Science of Being, Home of Truth, and even, until Eddy definitively copyrighted the term in the 1890s, Christian Science'. See Satter, op. cit. (38), p. 3. 
century. A rereading of both groups would locate Christian Science as merely the successful, Boston Brahmin version of a whole field of Christian mind-cure denominations, with New Thought as the Westward-looking, progressive, extreme wing. Prayer, for New Thought, verged on being a 'therapeutic, almost secular device' - and the movie theatre would be their cathedral. ${ }^{45}$

Film preoccupied New Thought thinkers from the beginnings of the medium. A typical New Thought publication such as Seeing the Invisible: Practical Studies in Psychometry, Thought Transference, Telepathy, and Allied Phenomena (1906) used the biograph, an early form of moving picture camera, as an extended analogy for the invisible attributes of the natural world that readers could be trained to detect. Specifically, it was argued that the mind can uncover 'nature's invisible biograph', including auras, or indeed thoughts. ${ }^{46}$ Other New Thought texts used film as analogy for the 'objective world', to suggest its malleability and simulacral quality: 'the idea that the entire visible universe is a moving picture of subjective thoughts which project it'. ${ }^{47}$

The greatest New Thought preoccupation with moving pictures was its symmetry with the abiding tenet of 'mental pictures'. This term was already in use by the progressive wing of nineteenth-century education reform. 'Mental pictures' was a key concept for educators, and in 1861 a book with this title was published, aiming to help children recall Bible stories by developing strong mental pictures of them - echoing the techniques of the 'art of memory' of antiquity. Early film boosters recognized that the moving picture could build upon this pre-existing philosophy. Even Thomas Edison used this terminology, in his 'Plea for the motion picture': 'A printed description is obviously incomplete, and mental pictures are formed that are generally incorrect'. But,

if geography were taught by moving pictures, if foreign lands and cities were illustrated, if the topography and general characteristics were shown, if the habits and demeanor of the people were depicted, and if their occupations and methods of work and recreation were illustrated, the child would have as clear an idea of everything as if the original scenes were viewed directly. ${ }^{48}$

45 Eva S. Moskowitz, In Therapy We Trust: America's Obsession with Self-Fulfillment, Baltimore: Johns Hopkins University Press, 2001, p. 20. The enthusiasm for the cinema felt by New Thought adherents is difficult to overstate, and New Thought was correspondingly popular in Hollywood. Perley Poore Sheehan, a New Thought practitioner and Hollywood screenwriter, invested the cinema with a great prospective moral weight that was typical of New Thought in his book Hollywood as a World Center: 'The cathedrals stimulated and conserved all the arts of their time. So does the motion-picture. The cathedrals arose in response to a mass hunger not of the flesh. So has the motion-picture. The cathedrals were the expression of a great faith. So also, we cannot too strongly affirm, will be the motion-pictures of this new era ... The motion picture of tomorrow will present mind, imagination, alive and at work'. Perley Poore Sheehan, Hollywood as a World Center, Los Angeles: Hollywood Citizen Press, 1924, p. 86.

46 'The marvels of nature's biograph will, possibly, never be discerned by any one individual, however gifted; but to the educated sense of many, much which is now hidden may be revealed, as picture after picture unfolds before the eye of the psychic'. See James Coates, Seeing the Invisible: Practical Studies in Psychometry, Thought Transference, Telepathy, and Allied Phenomena, London: Fowler, 1906, p. 50.

47 Ernest Holmes, New Thought Terms and Their Meanings, New York: Dodd, Mead, 1942, p. 100.

48 See Frank Parker Hulette, 'An interview with Thomas A. Edison', Moving Picture World (22 July 1911) 9, pp. 104-105, 105. 
Notably, the addition of movement to the extant concept of mental pictures, which was heretofore premised upon photography or painting, was key. ${ }^{49}$ The speed of moving pictures was seen as a crucial advantage in their pedagogic utility. Sparks introduced a typical period view that 'the eye learns more rapidly than the ear', and 'light travels faster than sound', adding to this premise the 'dynamic',50 'active' cinema that could best 'chain the attention' of the viewer. ${ }^{51}$ Cinema, with its speed, was the only medium to match the pace of thought, and so better impressed imagery upon the mind.

Rather than a simple mnemonic device, we might call New Thought's use of mental pictures 'creative visualization' or 'positive thinking' today-each concept analogous to, if not directly descended from, New Thought practice. At the time, however, the mental picture was a conceptual lynchpin of New Thought practice - practically every publication made reference to it - and they could be positive or negative, with corresponding physical outcome. Nuggets of New Thought, a typical advice manual, proposed, 'Get rid of your old, gloomy mental pictures - Make a bonfire of them - Get rid of the particularly miserable one, first of all-Then put bright ones in their places'. ${ }^{52}$ Mental pictures were crucial, given their imaginative and transformative power over the unborn. As a writer in Unity, one of New Thought's long-running journals and churches, phrased it, 'The mother is just as much the creator of her own child as the artist is of his picture, or the composer of his music'. ${ }^{53}$ Children are media made with their mother's influences, including cultural ones.

Prenatal culturing (distinct, but related to, maternal impression) was everywhere in New Thought as well as Christian Science; its most prominent members addressed the topic, and all agreed on the power of nurture over nature. ${ }^{54}$ Mary Baker Eddy, the founder of the Church of Jesus Christ, Scientist, developed a class in 'metaphysical obstetrics' that she taught at the Massachusetts Metaphysical College. In the notes that survive from the course, Eddy argued against the 'prenatal mesmerism' that was the idea of heredity, and instead for the 'prenatal influence' of the mother. ${ }^{55}$ Ella Wheeler Wilcox, meanwhile, demonstrated the 'power of prenatal influence' with the example of Napoleon, whose 'mother read Roman history with absorbing interest during the months preceding his birth'. 'Think of the nations and the centuries influenced

49 For a bestselling New Thought manual that used photography as the analogic premise for mental pictures see Henry Wood, Ideal Suggestion through Mental Photography: A Restorative System for Home and Private Use, Preceded by a Study of the Mental Healing, Boston: Lee and Shepard, 1893.

50 Metcalfe, op. cit. (26), p. 7.

51 Metcalfe, op. cit. (17), p. 10.

52 William Walker Atkinson, Nuggets of the New Thought, Chicago: Psychic Research, 1902, p. 73. According to one of the first histories of New Thought, this focus on mental pictures went back to Quimby himself. See Horatio Dresser, History of the New Thought Movement, New York: Thomas Y. Crowell, 1919, p. 137.

53 Christian Larson, 'Every child has the right to be born great', Unity (January 1910) 32, pp. 152-158, 156.

54 On prenatal culturing see Sara Dubow, Ourselves Unborn: A History of the Fetus in Modern America, Oxford: Oxford University Press, 2010, pp. 24-28. For New Thought texts that treat prenatal culturing and maternal impression see Erastus Hopkins, Science of the New Thought, Bristol, CT: New Thought Book Concern, 1904; and Horatio Dresser, The Spirit of the New Thought, New York: Thomas Y. Crowell, 1917.

55 Alfred E. Baker, 'Notes on metaphysical obstetrics', manuscript (Providence, 1935). 
by that one woman's mental concentration!' she continued, 'The geography of the world was changed by her power of focused thought'. ${ }^{56}$

Prenatal culturing was no small matter; it could rise to the level of geopolitics. For Wilcox, a writer, it was the printed word that carried the most power; she urged the expectant mother to strategically 'read inspiring books'. ${ }^{57}$ Prior to the rise of cinema, however, New Thought writers customarily looked to painting to provide the right kind of mental pictures for pregnant women. Testaments of successful New Thought practice were often gathered into collections, with the gathered stories meant to be object lessons for the reader. Alongside success stories of individuals, say quitting tobacco use, or healing tuberculosis through the use of mind-cure techniques, prenatal culturing stories such as the following were ubiquitous in the literature:

I knew a frivolous little butterfly who determined that her first child should be born with yellow curly hair and blue eyes, though all her relatives and her husband's were dark and straight haired. Every day this little woman gazed long and often at the picture of a beautiful child she had seen, and imagined and willed her child to be like it. And he was - the most seraphic little blue-eyed, curly-golden-haired cherub I ever saw. ${ }^{58}$

This story has a happy ending, according to the arguably eugenic values of New Thought, because the mother knew to use New Thought methods and had access to a strong picture on which she could premise her mental pictures. What of those expectant mothers who were not aware of the benefits of beautiful images on the unborn, or, worse, did not have access to them? How were they to be prenatally cultured, even without their knowing? The fine arts would be of no assistance. In the book Maternal Impressions, purity advocate Charles Bayer dismissed the prospect of making museums free to the poor, since it would be merely '[f]eeding a hungry lion with rose leaves'. All such efforts to 'elevate the criminal classes' were doomed to 'failure until the slum element becomes mentally able to appreciate art'. ${ }^{59}$ The answer, then, was cinema, which required no expertise, and which the poor could and already did participate in. This was Electra Sparks's insight.

\section{Sparks's cinema}

Sparks believed so earnestly in the power of the cinema's mental images, that she suggested that a New York film censor of her acquaintance, who 'had witnessed thousands and thousands of films during the last few years', was correspondingly 'one of the most beautiful women [she had] ever seen', made beautiful by this viewing practice. ${ }^{60} \mathrm{Her}$

56 Ella Wheeler Wilcox, The Heart of the New Thought, Chicago: Psychic Research Company, 1902, p. 88.

57 Wilcox, op. cit. (56), p. 90.

58 Elizabeth Towne, How to Use New Thought in Home Life, London: Fowler, 1921, p. 121. See also the contributions 'How a mother influenced the beauty of her children' and 'The story of an "ugly duckling" made over', in Towne, 53 Experiences in New Thought, London: Fowler, 1920.

59 Charles Bayer, Maternal Impressions: A Study in Child Life before and after Birth, and Their Effect upon Individual Life and Character, Winona, MN: Jones and Kroeger, 1897, p. 79. For more on Bayer see Pernick, op. cit. (32) p. 207 n. 23.

60 Metcalfe, op. cit. (14), p. 23. 


\section{2}

belief in the power of the cinema's mental images was so fervent that she set to work advocating for a New Thought cinema that would provide the appropriate mental images.

Sparks began by petitioning movie producers themselves, in lectures and via the pages of the Moving Picture News: ${ }^{61}$

Let those whose culture began before they were born; those who have gone in the business of manufacturing films for popular demand begin now and create a desire of the masses to see such pictures projected that will impress the mental films of unborn babies, and begin thus the first steps in primary education of the unborn race. ${ }^{62}$

Her appeal did not necessarily go unheard, but there was no immediate response. So it was that in 1911 and 1912 she began three separate series of educational film screenings for the children of Staten Island. At the Richmond, Park and Odeon theatres she made arrangements to screen matinees or Sunday morning programmes. These educational screenings were, she wrote, a 'copyright-canned idea of new thought', and she personally selected the films, a number of which were the product of New York-based film studio the Thanhouser Company. These included respectable classics such as The Tempest (1911) or The Siege of Troy (1911), ${ }^{63}$ scenics featuring the San Catalina Island and Lake Garda, and fairy tales The Pied Piper of Hamelin Town (1911) and Cinderella (1911). Sparks would lecture between the films, which had the brief lengths typical of early cinema, and the series was (self-reportedly) successful, attracting hundreds to the eight-hundred-seat Richmond Theatre. ${ }^{64}$

Her efforts to curate New Thought values into regional screening practice were ultimately in vain, since the local laws maintained that it was 'against the law for children under 16 to go in a moving picture palace unaccompanied'. ${ }^{65}$ The police broke up one of her screenings as it was in progress, and that seems to have ended the experiment in fact, her account of this raid is her final published article in the Moving Picture News. She deplored the law's inability to distinguish between her educational programming and such vaudevillian material as you might find in a working-class Bowery movie theatre. But this was not Sparks's only attempt to forge a New Thought cinema.

As she was running her screening series, she also published a manifesto claiming the 'Ten Links in moral and mental development, which can be taught and idealized through the moving picture apparati'. These 'links' were a lexicon of New Thought values: interest and cheerfulness, imagination and ideality, kindness and sympathy, emulation and industry, courage and resourcefulness, observation and investigation, thought and reason, patriotism and fidelity, ambition and tenacity of purpose, spirituality and

61 One report of her speaking style remains. A patronizing account in the New York Times described Sparks as 'a middle-aged woman', who spoke 'after the manner of the Shakespeare tragedies'. Granted, this speech was supposedly on the dangers of 'adulterated pies', but it gives an impression of Sparks's potential reception. See 'Gotham Club as a "salon"', New York Times, 16 November 1910.

62 Metcalfe, op. cit. (8), p. 15.

63 It is likely that she screened not The Siege of Troy, but The Fall of Troy (1911), which is more commonly referenced, although it may be simply that little record of the former film remains.

64 Metcalfe, op. cit. (13).

65 Metfalfe, op. cit. (14). 
culture. ${ }^{66}$ This jumble of key words - which are left unelaborated in the manifesto might not have offered a coherent set of guidelines for the sympathetic film producer, but Sparks also provided a script, or outline for a moving picture (she called it 'Mental Films for a Picture Story'). It gives some sense of the type of cinema that she might have hoped for.

Tellingly, the film is concerned with neonatal culturing. Called 'The captain's treasure', it begins with a disaster at sea, and the captain (a lighthouse keeper) who attempts to save a washed-up baby girl thought dead: 'There is life in the little storm-beaten body. The women work on the baby. They clamor to get possession of it. The captain steps among them and takes the treasure for himself.' 67 The captain takes the baby home to the lighthouse to raise her. Again, local women contest his parentage:

Six fishwives cross the bridge and climb the lighthouse stair. They enter the 'Cap'n's' cabin and see him feeding the baby. Makes a funny face, and shows he has no experience with 'leetle gals'. The visitors make merry at his awkward handling and feeding of a baby. Again they put out their hands and offer to adopt it. 'Cap'n' shakes his head and hugs the baby to his breast. ${ }^{68}$

The outline then cuts to various vignettes in the later life of the baby (Pearl): as an older child, doting on the captain, whom she has chosen over a blood-relative uncle; meeting her suitor, who likewise rescues her from the water, this time in a swimming accident; and, following the death of the captain, her 'society wedding' and honeymoon. The end.

The captain, not unlike Sparks's prenatal cinema, is an improbable educator. His suitability is questioned repeatedly, but he is ultimately a successful parent, and one who exemplifies a number of Sparks's favoured values: kindness and sympathy (rescuing Pearl); courage and resourcefulness (raising her); fidelity (to his foundling); and spirituality and culture (marriage and the society wedding). The script mirrors the advice literature on parenting that New Thought writers engaged in at the time (and which was simultaneously booming for publishers), and also reflects the progressive gender politics of New Thought practitioners who, like Christian Scientists, were predominantly women.

New Thought values are, in short, embedded in the picture. But how to impress them upon the minds of the viewer? Throughout, Sparks punctuates the narrative with striking images of light: 'One long beam falls on the roaring waters from the great white light of the tower', 'A great ball of fire rises over stormy waters', the captain 'throws wood into the open stove and makes a blaze'. ${ }^{69}$ These images were to brand the strong values of the moving picture indelibly upon the mental picture of the viewer; to brand, perhaps, the expectant mother and her child.

Sparks's script was never made into a film, and beyond 1913 there is little record of her activities; apart from writing film synopses in the 1920s she had nothing more to do with

66 Mary Lawton Metcalfe, The Moving Picture World (11 November 1911) 10, p. 457.

67 Mary Lawton Metcalfe, 'The captain's treasure: mental films for a picture story', Moving Picture News (20 December 1911) 4, pp. 16-17, 17.

68 Metcalfe, op. cit. (67).

69 Metcalfe, op. cit. (67). 
cinema. ${ }^{70}$ (By 1917 she had moved to Florida, where she died in $1949 .{ }^{71}$ ) Nevertheless, her push for a New Thought cinema had an unlikely, if unconnected, fruition in Hollywood later in the 1910s, when actor Douglas Fairbanks and director Cecil B. DeMille dabbled in it. Reaching for the Moon (1917), which starred Fairbanks, would likely have disappointed Sparks, as the premise of the film was to 'poke fun at New Thought'. As the film's director and writer put it, 'Suppose we start with this young American and make him a rabid believer in New Thought. Let him think that anything on earth he wants (no matter whether he is entitled to it or not) he can get simply by concentrating on it'. ${ }^{72}$ Fairbanks's protagonist, Alexis Caesar Napoleon Brown, comes under the ill influence of an explicitly New Thought tract titled Concentration. ${ }^{73}$ Intertitle extracts from the book provide an accurate satire, and preserve some of the key terminology: 'You can make yourself a towering figure in the world through the power of concentration. Think hard of what you wish to be and hold the mental picture - concentrate on it and it will be come true'. Ultimately, Fairbanks's character imagines himself a king, conspiracy ensues, and things go badly; it is a cautionary tale against the techniques of New Thought.

By the mid-1920s New Thought had become a Hollywood punchline. The debut issue of journalist H.L. Mencken's American Mercury in 1924 featured a withering attack on New Thought and its techniques, framing the method as follows: 'A boy of twelve admires Charlie Chaplin. He sets his subjective mind to work that night, and wakes up with a fine little mustache'. ${ }^{74}$ The author echoes an earlier poem critical of New Thought, which details failed attempts to use imaging techniques for personal beautification. It concludes, 'On mental pictures, you bet, I waste no more time / Motion pictures, or none, hereafter, for mine'. ${ }^{75}$ However, Electra Sparks's failure to see the cinema she envisaged produced, and the decline of New Thought as a movement, do not make it irrelevant to film history and theory, or indeed to contemporary film and media.

70 See, for instance, her review of Carolina Belle in Talking Picture Magazine (December 1929) 1, p. 19.

71 Her theories come progressively unhinged, as shown in a bizarre, unintelligible manuscript printed in the Washington Times (unsolicited, they reassure the reader). The piece is called " Real-I-zation" and the cosmos', with the subtitle given by the newspaper: 'We never saw realization spelled THAT way before, hence this editorial'. Lawton's theory seems to have developed curiously: 'I realize a great Rock of Truth looms up in the Silent Sea of Thought. The tide has swept far out, and on this Rock of realization I am a growth of this substance: the Substance of Mind. Like the sea sponge, every cell of my being is made, nourished, sustained in the actual Sea of Being'. See Washington Times, 23 November 1917, p. 20.

72 John Emerson and Anita Loos, 'Photoplay writing', Photoplay (April 1918) 13, p. 82.

73 It is likely that this filmic Concentration is directly inspired by the writings of New Thought author Annie Rix Militz, who used 'concentration' as a key word in all of her writing, from Spiritual Housekeeping: A Study in Concentration in the Busy Life, Los Angeles: Master Mind, 1910, to Concentration, Los Angeles: Master Mind, 1918. On the roots of today's not dissimilar 'mindfulness movement' see Ayesha Nathoo, 'From therapeutic relaxation to mindfulness in the twentieth century', in Felicity Callard, Kimberley Staines and James Wilkes (eds.), The Restless Compendium: Interdisciplinary Investigations of Rest and Its Opposites, Basingstoke: Palgrave Macmillan, 2016, pp. 71-80.

74 Woodbridge Riley, 'The New Thought', American Mercury (January 1924) 1, p. 107.

75 Marie E. Lefferts, 'My choice', Motion Picture (February 1913) 5, p. 60. 


\section{New Thought film theory}

As in the case of, for instance, spirit photography, widely held but subsequently discredited beliefs can reveal much about our attitudes toward new technologies. ${ }^{76}$ They can even reveal hidden tributaries of contemporary understanding. I propose here that Sparks's apparently fringe film theory is surprisingly consonant with, and indeed presages, one of the abiding preoccupations of both classical and contemporary film theory: the isomorphism between mind and film, between mental picture and moving picture.

Some of this was merely incidental. The poet Vachel Lindsay, in his early appreciation The Art of the Motion Picture (1916), claimed that the coming of film replaced the verbal thinking of the proletariat, their 'cunning of the tongue', with an imagistic cognition: they began to 'think in pictures'. ${ }^{77}$ For Lindsay, this transition was positive, due to film's educative capacity; the world would become an 'imaginary playground', and all would have advance familiarity with its cities. ${ }^{78}$ Although Mencken once accused Lindsay of spouting only 'New Thought dithyrambs', Lindsay's connections to the group were apparently nil. ${ }^{79}$ The symmetry between his and Sparks's valuation of the cinema for its capacity to produce new mental pictures was accidental, part of the zeitgeist of responses to the newly ascendant medium. Other symmetries were not.

New Thought has had a wide, and to this point unexamined, impact on film theory via the work of Hugo Münsterberg, the Harvard psychologist whose film theories in The Photoplay (1916) have undergone a scholarly renaissance. Münsterberg took for granted that cinema, as a new medium, would develop new relations between the mind and body for viewers. Like Sparks, he thought that cinema could be emancipatory; ${ }^{80}$ like Sparks, he developed a complex equivalence between processes of mind and processes of cinema; ${ }^{81}$ and like Sparks, he allowed not only for the idea that the formal operations of the film mirrored thought (the flashback as memory, the flashforward as imagination), but also for moving pictures that physiologically 'mark' the viewer. In an average film viewing experience, Münsterberg claimed, 'abnormal visual impressions stream into our consciousness, [and] our whole background of fusing bodily sensations becomes altered and new emotions seem to take hold of us'. If a viewer sees a hypnotized man on screen, say, and the filmmaker formally reflects his

76 Tom Gunning, 'Phantom images and modern manifestations: spirit photography, magic theater, trick films and photography's uncanny', in Patrice Petro (ed.), Fugitive Images from Photography to Video, Bloomington: Indiana University Press, 1995, pp. 42-71.

77 Lindsay accordingly developed a dense system of hieroglyphic film interpretation in Vachel Lindsay, The Art of the Motion Picture, New York: Macmillan, 1916, pp. 185-186.

78 Lindsay, op. cit. (77), p. 186.

79 H.L. Mencken, 'The troubadours a-twitter', Smart Set (May 1915) 46, pp. 150-156, 152.

80 Robert Brain, 'Self-projection: Hugo Münsterberg on empathy and oscillation in cinema spectatorship', Science in Context (September 2012) 25, pp. 329-353.

81 Noël Carroll, 'Film/mind analogies: the case of Hügo Munsterberg', Journal of Aesthetics and Art Criticism (Summer 1988) 46, pp. 489-499; Brain, op. cit. (80); and Alison Winter, Memory: Fragments of a Modern History, Chicago: The University of Chicago Press, 2012. Note that although present-day cognitive science also uses the terminology of 'mental pictures', this is an erroneous connection having little to do with the tradition that I discuss here. 
state by having the space represented on screen begin 'to tremble and then to wave and to change its form more and more rapidly', the viewer would reciprocate in kind, and themselves become hypnotized, 'seized by the strange emotion'. ${ }^{82}$

The apparent congruence between Sparks's theory and Münsterberg's, and the physiological power they each afford to cinema, is not accidental. Münsterberg was already familiar with the European milieu of 'physiological aesthetics', the scientific study of the effects of art on the body. ${ }^{83}$ His experimental psychology reflected this interest, and especially his interest in the motion pictures. These extant interests were put to work in a Cambridge-Boston milieu during which Christian Science, and its focus on the impact of the mind on the body (the mind-cure), was ascendant. The values of physiological aesthetics and the mind-cure found an easy symmetry in Münsterberg's approach; each is a practical synonym for 'psychotherapy'. Münsterberg was a well known and highly positioned sympathizer of mental healing. Writing so proximately to Boston in these years, he was quite familiar with Mary Baker Eddy and allied movements based there. His landmark text, Psychotherapy (1909), took seriously the mindcure, and aimed to make it palatable to scientists.

Christian Science is everywhere in Psychotherapy: Münsterberg quotes Eddy at length, ${ }^{84}$ and argues in favour of Christian Science techniques as a 'symptom of transition' from a popular, religious psychotherapy to a scientific one. ${ }^{85}$ It has even been claimed that Münsterberg was a 'great early contributor to the translation of New Thought narrative into scientific discovery'. ${ }^{86}$ New Thought journals embraced his work as well; one claimed that Münsterberg 'could be read with profit both before the study of New Thought books and also subsequently to the reading of a dozen of them'. ${ }^{87}$ Münsterberg may have encountered Sparks's writing directly, given his readings in both the mind-cure movement and early film journals. In any case, his awareness of this general philosophy had an impact on his own.

Owing perhaps chiefly to Münsterberg's continued relevance in film studies, New Thought film theory is today back in fashion. The same terminology even recurs: 'Motion pictures unfold mental pictures, and such pictures actually "move" us'. This might be Electra Sparks writing in 1911; in fact, it is film theorist Giuliana Bruno, writing in 2014. ${ }^{88}$ The idea that the cinema marks us, changes us physiologically, became a key area of inquiry in film studies - in the turn to phenomenology by scholars

82 Hugo Münsterberg, The Photoplay: A Psychological Study, New York: D. Appleton, 1916, p. 128.

83 On Münsterberg's debt to physiological aesthetics see Brain, op. cit. (80); on physiological aesthetics and its impact on the arts see Robert Brain, The Pulse of Modernism: Physiological Aesthetics in Fin-de-Siècle Europe. Seattle, WA: University of Washington Press, 2016.

84 Hugo Münsterberg, Psychotherapy, New York: Moffat \& Yard, 1909, p. 327.

85 Münsterberg, op. cit. (84), p. x.

86 Mauro F. Guillén, Models of Management: Work, Authority, and Organization in a Comparative Perspective, Chicago: The University of Chicago Press, 1994, p. 44.

87 John Benjamin Anderson, New Thought: Its Light and Shadows: An Appreciation and a Criticism, Boston: Sherman, French \& Co, 1911, p. 147.

88 Giuliana Bruno, Surface: Matters of Aesthetics, Materiality, and Media, Chicago: The University of Chicago Press, 2014, p. 29. I note that Bruno has published on Münsterberg, from whom she may have adopted the formulation. 
such as Linda Williams and Vivian Sobchack, ${ }^{89}$ as well as in the 'modernity thesis' debates. ${ }^{90}$ Likewise, the symmetry between mind and screen is often taken as a given by present-day film theorists - and, increasingly, by new media scholars. Assuming a homology between 'mental representations and operations with external visual effects such as dissolves ... and edited sequences' is not Münsterberg in 1916; rather, it is Lev Manovich in 2001.91

If these sentiments seem niche or esoteric, one must only recall the ongoing, de facto provision against pregnant women viewing certain types of film - those from the horror genre, in particular. ${ }^{92}$ There exists a cottage industry of online 'listicles' warning of 'the films no pregnant women should see'. The implied result of maternal impression is customarily sublimated. Sparks-like concerns maintain not only at the popular level, but in the sciences as well. There has been a century of study on the physiological effects of cinema-on, for instance, the power of immersive film experiences to habituate viewers to motion sickness, or for $3 \mathrm{D}$ viewing glasses to strengthen the eye - but a recent experiment in Japan put New Thought theories to the test. In 2010, researcher Kazuyuki Shinohara and colleagues aimed to measure the effects of maternal emotions on the foetus, showing pregnant women

two empirically validated feature film clips [which] were used for the external generation of two subjectively and facially well-characterized target emotions, happiness and sadness. The happiness-inducing film clip was taken from The Sound of Music and depicted a scene of a female teacher smiling and singing for children. The sadness-inducing film clip was from The Champ, in which a boy cries at the death of his father ... An emotionally neutral film clip was used to control for potentially confounding features of the emotion-generating film task, such as emotionally irrelevant visual stimulation and eye movement. This clip consisted of many figures slowly appearing, disappearing or moving around. ${ }^{93}$

Throughout, two ultrasound scanners were employed, monitoring foetal arm and leg movement respectively. The result: arm movement increased correspondent to the happiness of the mother; and less movement was detected during response to sad scenes. The results were reported in New Scientist with the title 'If mum is happy and you know it, wave your arms', and they have already been included in advice guides for pregnant women, alongside prenatal culturing tools such as the Baby Mozart series. ${ }^{94}$

The survival, or revival, of this line of thought in the present day was by no means a given. Many early film theories are no longer meaningfully in practice. Such questions -

89 See Vivian Sobchack, Carnal Thoughts: Embodiment and Moving Image Culture, Berkeley: University of California Press, 2004; and Linda Williams, 'Film bodies: gender, genre, and excess', Film Quarterly (Summer 1991) 44, pp. 2-13.

90 For a summary of the debate see Ben Singer, Melodrama and Modernity: Early Sensational Cinema and Its Contexts, New York: Columbia, 2001, pp. 101-130.

91 Lev Manovich, The Language of New Media, Cambridge, MA: MIT Press, 2001, p. 73.

92 Between the 1930s and the 1960s film censors argued that the reality of pregnancy or childbirth turned any film into a horror film. See David A. Kirby, this issue.

93 Miyuki Araki, Shota Nishitani, Keisho Ushimaru, Hideaki Masuzaki, Kazuyo Oishi and Kazuyuki Shinohara, 'Fetal response to induced maternal emotions', Journal of Physiological Sciences (2010) 60, pp. 213-220, 214.

94 Jessica Hamzelou, 'If mum is happy and you know it, wave your arms', New Scientist (2010) 205, p. 11. 


\section{Patrick Ellis}

does the moving image have a physiological effect? Does the mind operate cinematically? - ebb and flow in the histories of film theory and science. Perhaps on account of the present-day reckoning with the digital revolution's new and destabilizing viewing practices and cultures, these questions have had a renaissance. The New Thought premise of such theory should now be clear. With an assumption that mind-cures of physical ailments are possible, New Thought film theory can proceed easily from the literal (film impacts physiology) to the analogical (film is homologous with mind).

Similarly, the role of reproduction in this essay has ranged from the reproduction of a new mass generation of foetal viewers to be prenatally cultured by the newly accessible media of cinema, to the reproduction of filmic processes in the body and the mind. Although these may appear to be discrepant forms of reproduction, they form a basically structured relationship, one premised, during cinema's second birth and now, on the strange power and possibility of emergent media. In this sense, the present-day interest in these questions retains Sparks's utopian view: that access to cinema will be ubiquitous, its influence profound, felt at the deepest levels of being. 